\section{Differential Effects of Lower Day and Night Soil Temperatures on Shoot and Root Growth of Creeping Bentgrass}

\author{
Qingzhang $\mathrm{Xu}^{1}$, Bingru Huang ${ }^{2}$, and Zhaolong Wang ${ }^{1}$ \\ Department of Plant Biology and Pathology, Rutgers University, New \\ Brunswick, NJ 08901
}

Additional index words. Agrostis palustris, summer bentgrass decline, heat stress

\begin{abstract}
Turf quality of creeping bentgrass (Agrotis palustris L.) often declines during summer months. Reducing soil temperature alleviates bentgrass quality decline at supraoptimal air temperatures. The objective of this study was to investigate whether reducing soil temperature during the night is more effective than during the day in improving shoot and root growth when air temperature was supraoptimal for creeping bentgrass. The experiment was conducted in growth chambers using water baths to manipulate soil temperatures. Plants were exposed to the following temperature treatments: 1) optimal air and soil temperature during the day and night $\left(20 / 20^{\circ} \mathrm{C}\right.$, day/night, control $\left.) ; 2\right)$ high air and soil temperature during the day and night $\left(35 / 35{ }^{\circ} \mathrm{C}\right.$, day/night); 3) lower soil temperatures during the day $\left(20 / 35,25 / 35\right.$, and $30 / 35{ }^{\circ} \mathrm{C}$, day/night); and 4) lower soil temperature during the night $\left(35 / 20,35 / 25\right.$, and $\left.35 / 30{ }^{\circ} \mathrm{C}\right)$ while air temperature was maintained at $35^{\circ} \mathrm{C}$ during the day and night. Turf quality (on 1-9 scale) increased to the level of $6.5,3.0$, and 2.5 by reducing day soil temperature to 20,25 , or $30{ }^{\circ} \mathrm{C}$, respectively, at 28 days of treatment, compared to the quality of 2.0 at $35 / 35{ }^{\circ} \mathrm{C}$. Turf quality increased from 2.0 at $35 / 35{ }^{\circ} \mathrm{C}$ to $7.0,6.0$, and 4.5 , respectively, by 28 days of exposure to night temperatures of 20,25 , and $30{ }^{\circ} \mathrm{C}$. Chlorophyll content, root number, and root weight also were increased by reducing day or night soil temperature, and the increases were more pronounced for reduced night temperatures than day temperatures. These results demonstrated that reduced night soil temperature was more effective than reduced day soil temperature in improving shoot and root growth in creeping bentgrass under high air temperature conditions.
\end{abstract}

Turf quality decline and root dieback of creeping bentgrass are common problems on golf greens during summer months (Carrow, 1996; Lucas, 1995). Summer air and soil temperatures in these areas often exceed the optimum range between 15 and $24^{\circ} \mathrm{C}$ for shoot growth and from 10 to $18^{\circ} \mathrm{C}$ for root growth of cool-season grasses (Beard, 1973). Supraoptimal temperature has been considered to be the primary environmental factor causing decline or death of creeping bentgrass in the summer, although many other factors can be involved (Beard and Daniel, 1965; Huang et al., 1998; Xu and Huang, 2000a, 2000b, 2001a).

High soil temperature is more detrimental than high air temperature for root and shoot growth of cool-season grasses (Beard and Daniel, 1965; Xu and Huang, 2000a, 2000b, 2001b). Reduction in soil temperature from 35 to $20{ }^{\circ} \mathrm{C}$ continuously when air temperature was at $35{ }^{\circ} \mathrm{C}$ helped maintain turf quality equivalent to those plants grown under optimal air and soil temperature conditions (Xu and Huang, 2000a, 2000b). A reduction in soil temperature by only $3{ }^{\circ} \mathrm{C}$ from $35^{\circ} \mathrm{C}$ also was effective in alleviating a decline in quality of creeping bentgrass (Xu and Huang, 2001b). Various methods, including fan (Taylor, 1995),

Received for publication $1 \mathrm{Feb}$. 2002. Accepted for publication 5 Aug. 2002.

${ }^{1}$ Research Associate.

${ }^{2}$ Associate Professor. E-mail address: huang@aes op.rutgers.edu) syringing (Carrow, 1996), and subair system (Dodd et al., 1999; Trusty and Trusty, 1998), have been used to reduce soil temperature to improve turf performance. However, continuous soil-temperature reduction can be costly and is difficult to achieve by routine management practices.

Night soil temperature often is higher than air temperature, especially when soils are moist. Reducing soil temperature during the night may be easier and more economically feasible than during the day, because night temperature is not affected by solar radiation. From physiological aspects of plants, lowering night temperature may increase carbohydrate availability by suppressing dark respiration (Poorter et al., 1991). Carbohydrate content in leaves of creeping bentgrass has been found to decrease during the dark period because all plant parts go through dark respiration, with no photosynthesis and carbohydrate production; in contrast, during the daytime, photosynthesis prevails and results in increased carbohydrate accumulation (Xu et al., 2003). However, whether reducing day or night soil temperature is more effective for improving turf quality of creeping bentgrass when air temperature is supraoptimal has not been investigated. Such information would be valuable for turfgrass managers in developing effective management practices to alleviate

The objectives of this study were to investigate whether reduced soil temperature during the night was more effective than during summer bentgrass decline. the day for improving turf quality and plant growth under high air temperature conditions and to determine the effectiveness of different levels of soil temperature reduction during the day or night.

\section{Materials and Methods}

Plant materials and growth conditions. Sod pieces of creeping bentgrass ('Penncross') were collected from the Rutgers Turfgrass Research Center at North Brunswick, N.J., and transplanted into clear polyethylene tubes $(5 \mathrm{~cm}$ in diameter and $40 \mathrm{~cm}$ in length, with eight holes drilled at the bottom for drainage) filled with fine sand. To prevent light exposure of roots, the polyethylene tubes were placed in opaque polyvinylchloride (PVC) tubes of the same inner diameter and length, which were installed vertically in water baths with the bottom end of each tube extended through the water bath for drainage (Fig. 1). The tubes were designed to enable plant growth to occur in a well-drained soil in polyethylene tubes, while soil temperature was controlled at a constant, predetermined level. Water levels were maintained at the top edge of the water bath and $0.5 \mathrm{~cm}$ below the top edge of the PVC tubes during the experimental period to keep soil temperature uniform from bottom to the top. The plant canopy was at the same level of the top edge of the PVC tubes, and the bottom of the plastic tubes was at the same level of the bottom of the water baths. Plastic tubes were isolated from water by the PVC tubes. Plants were grown in growth chambers at $20^{\circ} \mathrm{C}$ day $/ 15$ ${ }^{\circ} \mathrm{C}$ night, $600 \mu \mathrm{mol} \cdot \mathrm{m}^{-2} \cdot \mathrm{s}^{-1}$ photosynthetic photon flux density, and a 12-h photoperiod for 60 $\mathrm{d}$ before differential day/night soil temperature treatments were imposed. Before and during temperature treatments, turf was mowed daily at a 3-4 mm height with an electric hair clipper, watered daily until soil moisture reached field capacity (when free drainage ceased from the bottom of the plant containers), and fertilized weekly with $50 \mathrm{~mL}$ full-strength Hoagland's nutrient solution (Hoagland and Arnon, 1950).

Treatments. Plants were exposed to the following day/night temperature regimes: 1) control - optimal air and soil temperature during the day and night $\left(20 / 20{ }^{\circ} \mathrm{C}\right.$, day/night); 2) constant heat stress - high air and soil temperature during the day and night $\left(35 / 35^{\circ} \mathrm{C}\right.$, day/night);3) lowering soil temperatures to 20 , 25 , and $30^{\circ} \mathrm{C}$ during the day $(20 / 35,25 / 35$, and $30 / 35^{\circ} \mathrm{C}$, day/night) while air temperature was maintained at $35^{\circ} \mathrm{C}$ during the day and night. and 4) lowering soil temperature to 20,25, and $30^{\circ} \mathrm{C}$ during the night $(35 / 20,35 / 25$, and $35 / 30$ ${ }^{\circ} \mathrm{C}$ ) while air temperature was maintained at 35 ${ }^{\circ} \mathrm{C}$ during the day and night. Air temperature was regulated by a temperature controller in the growth chamber. Soil temperatures were manipulated by maintaining the entire root zone (40-cm-long soil column in a polyethylene bag) in water baths and circulating cool water $\left(18{ }^{\circ} \mathrm{C}\right)$ around the plant containers at variable rates to generate the different soil temperatures required $\left(20,25\right.$, and $\left.35^{\circ} \mathrm{C}\right)$ (Fig. 1; Xu and Huang, 2001b). Water was 
run continuously to maintain a constant and uniform temperature.

Air temperatures at $10 \mathrm{~cm}$ above the canopy and soil temperatures at different depths $(3,10$, and $25 \mathrm{~cm}$ ) below the surface were measured with thermocouples connected to a thermometer. Air and soil temperatures were checked twice during the photo- and dark period every day. In the control $\left(20 / 20^{\circ} \mathrm{C}\right)$, air temperature was maintained at $\approx 20^{\circ} \mathrm{C}$ and soil temperatures at 18 to $20^{\circ} \mathrm{C}$ (Fig. 2). At the $35 / 20,35 / 25$, and $35 / 30^{\circ} \mathrm{C}$ day/night temperature treatments, soil temperatures at $10-\mathrm{cm}$ depth during the night were 20,26 , and $30{ }^{\circ} \mathrm{C}$, respectively. At the $20 / 35,25 / 35,30 / 35$ treatments, soil temperatures at $10-\mathrm{cm}$ depth during the day were 20 , 26 , and $30^{\circ} \mathrm{C}$, respectively. A $12-\mathrm{h}$ photoperiod was used for the day/night temperature regimes to easily compare the importance of day and night soil temperature.

Experiment design and statistical analysis. Temperature treatments were arranged in a randomized block design with four replications. Measurements were made at various times of treatments to study prolonged response to temperature treatments. Plants were arranged randomly in each temperature regime in the water baths. All measurements were randomly taken in each treatment at various times of treatments. Each soil temperature treatment was run in four water baths as four replications. One water bath was placed in each of four growth chambers. Two sub-samples were taken per replication for each measurement. Thirty-two tubes per treatment were used for destructive sampling. Plants were swapped between chambers and water baths three times during the experiment to minimize equipment errors. Effects of temperature, time of treatment, and their interactions were determined by analysis of variance according to the general linear model procedure of the Statistical Analysis System (SAS Institute, 1996). The main effects of temperature and time of treatment and the interaction between temperature and time were significant at $P \leq$ 0.05 or 0.01 , except the interaction between temperature and time for relative root number (Table 1). Differences among treatments at a given time of treatment were determined by Fisher's protected LSD test at $P=0.05$.

Measurements. Turf quality was visually rated weekly after treatments were initiated based on color, density, and uniformity on a scale of 1 (worst, most plants died) to 9 (best, healthy and green plants). Grasses rated at six or above were considered to have acceptable quality. Vertical shoot extension rate was estimated every $3-5 \mathrm{~d}$ by measuring the difference in mean canopy height in a $1-d$ period using a ruler.

Plants were harvested weekly to determine leaf chlorophyll content and fresh weight and number of roots. Leaf chlorophyll content was measured according to the modified method of Hiscox and Israestem (1979). Chlorophyll from fresh leaf samples $(0.05 \mathrm{~g})$ was extracted in dimethyl sulfoxide for $48 \mathrm{~h}$ in darkness at room temperature before measurement. Absorbance was measured at 663 and $645 \mathrm{~nm}$ with a spectrophotometer (Spectronic Instru-

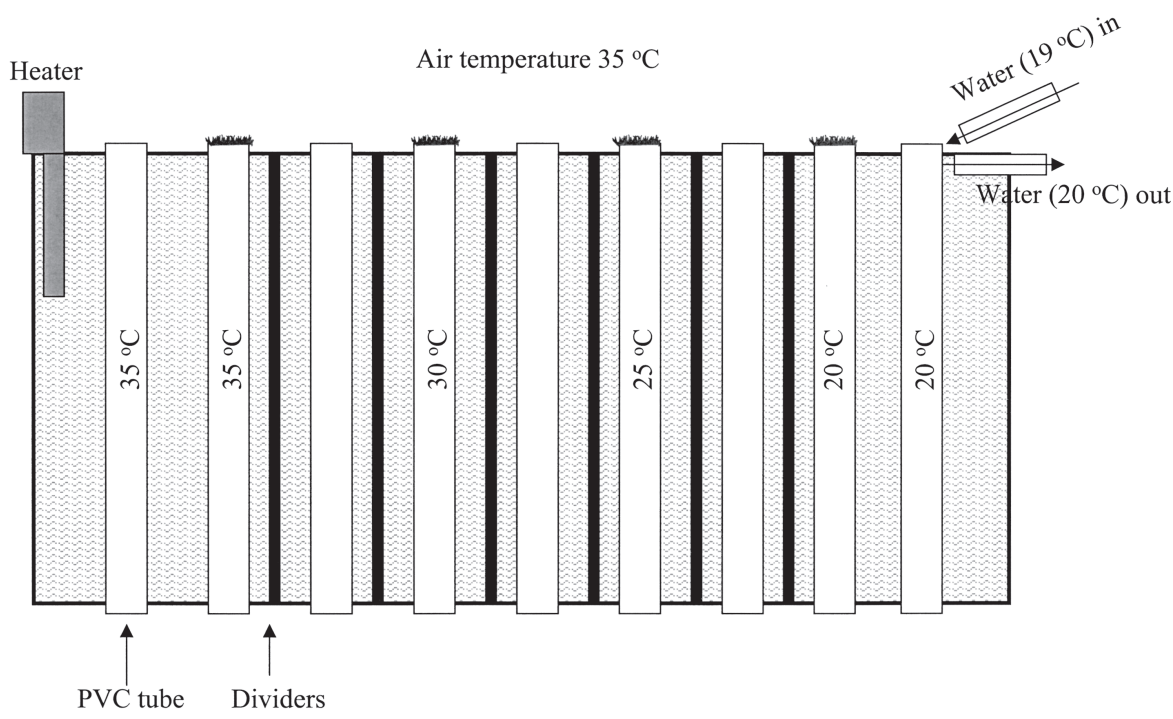

Fig. 1. Diagram of water bath controlling soil temperatures. Water bath was divided into seven compartments by PVC dividers. Ten PVC tubes were installed in each compartment, except there were 16 PVC tubes at both ends of the water bath. A heater was installed at one end of the water bath to heat water in this compartment to $35^{\circ} \mathrm{C}$. At another end of the water bath, cool water $\left(19^{\circ} \mathrm{C}\right)$ flowed through to control the temperature at $20^{\circ} \mathrm{C}$ by adjusting the flow rate. Heating and cooling at the opposite ends of the water bath created a temperature gradient along the water bath.

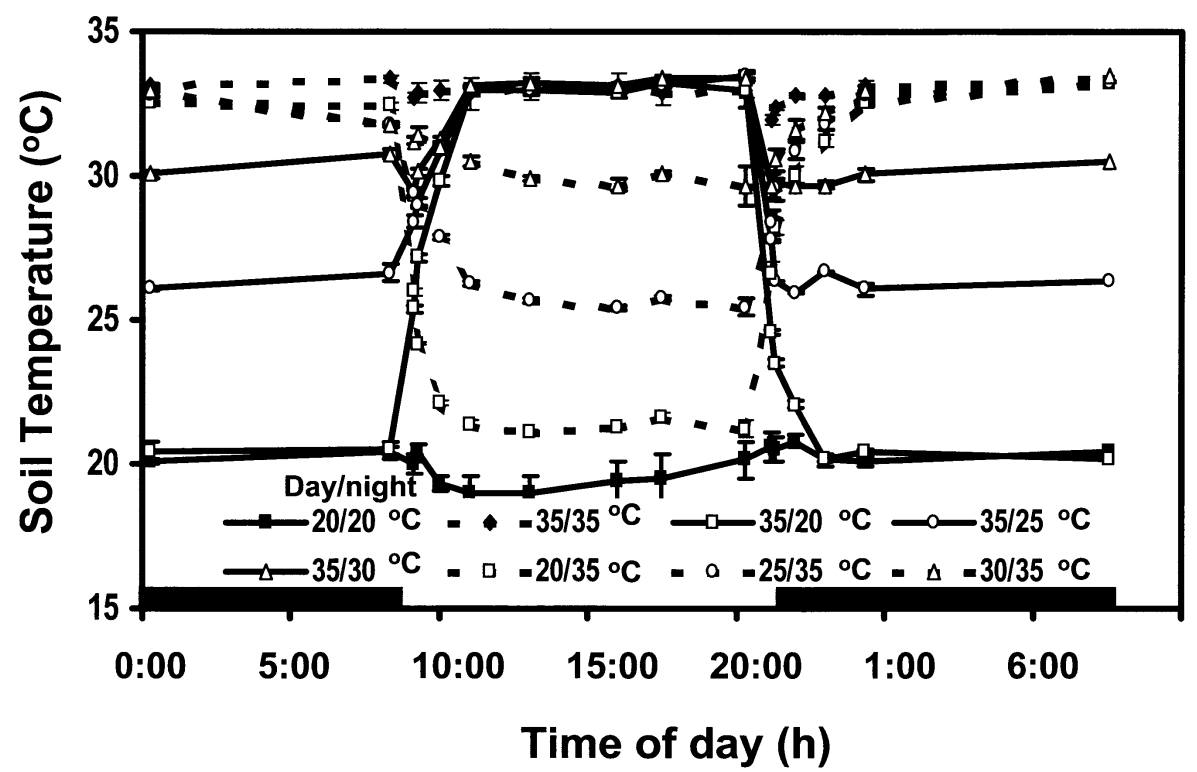

Fig. 2. Diurnal change of soil temperature $10 \mathrm{~cm}$ below the soil surface. Data points represent an average $( \pm \mathrm{SE})$ of four replicates. Black bars indicate nighttime.

Table 1. Analysis of variance (ANOVA) for various parameters as affected by differential day/night temperatures at different times of treatments for creeping bentgrass.

\begin{tabular}{lccccc}
\hline $\begin{array}{l}\text { Source of } \\
\text { variation }\end{array}$ & $\begin{array}{c}\text { Turf } \\
\text { quality }\end{array}$ & $\begin{array}{c}\text { Chlorophyll } \\
\text { content }\end{array}$ & $\begin{array}{c}\text { Shoot } \\
\text { extension rate }\end{array}$ & $\begin{array}{c}\text { Root } \\
\text { number }\end{array}$ & $\begin{array}{c}\text { Root } \\
\text { fresh weight }\end{array}$ \\
\hline Temperature (T) & $* *$ & $* *$ & $* *$ & $*$ & $*$ \\
Time (D) & $* *$ & $*$ & $* *$ & $*$ & $* *$ \\
$\mathrm{~T} \times \mathrm{D}$ & $* *$ & $*$ & $* *$ & NS & $*$ \\
\hline
\end{tabular}

${ }_{\mathrm{Ns},}^{*, * *}$ Nonsignificant or significant at $P \leq 0.05$ or 0.01 , respectively. 


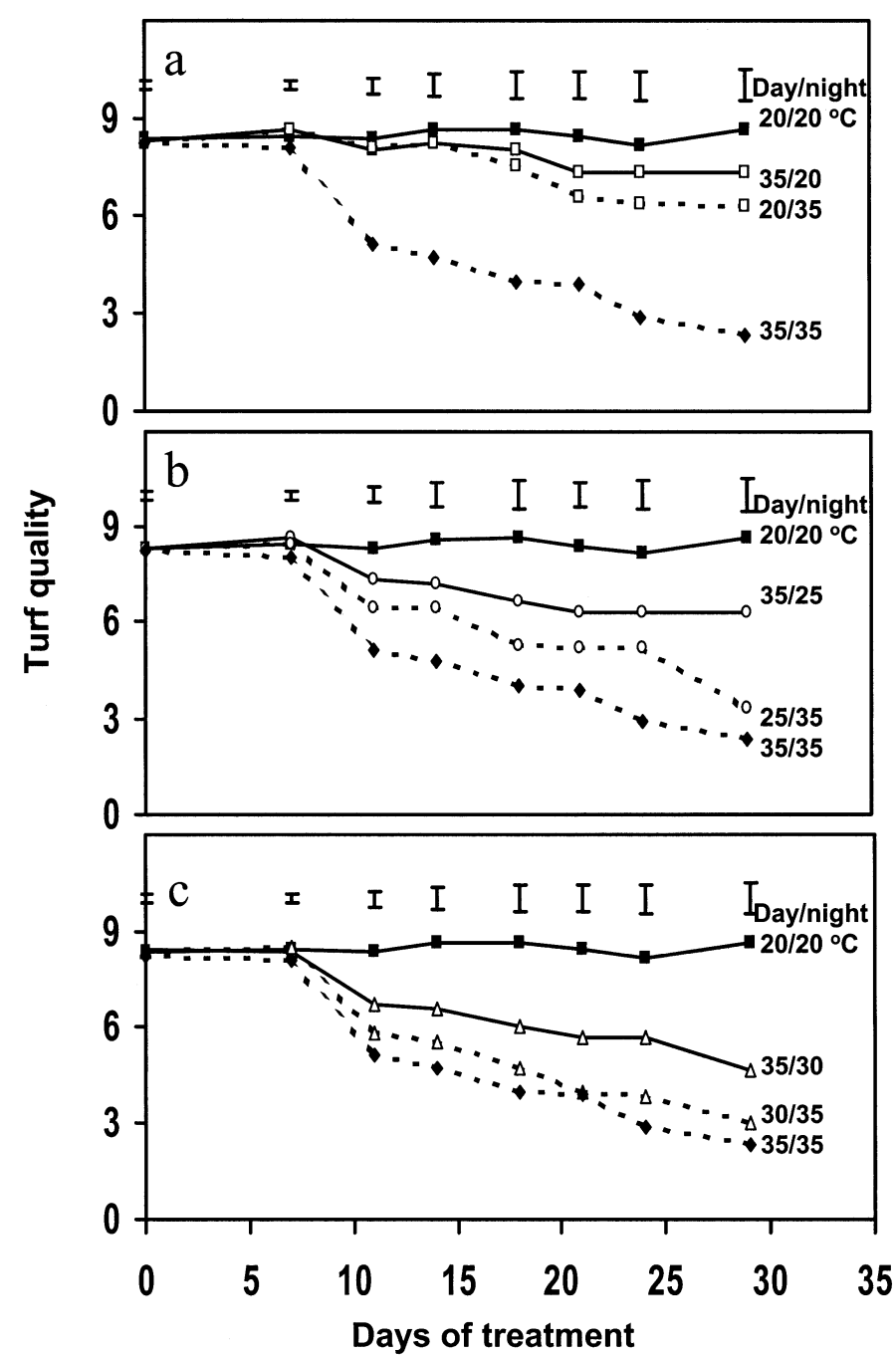

Fig. 3. Turf quality as influenced by lower day or night soil temperatures: (a) day/night soil temperatures at $20 / 35$ and $35 / 20^{\circ} \mathrm{C}$ are compared with the low temperature control $\left(20 / 20^{\circ} \mathrm{C}\right)$ and constant heat stress $\left(35 / 35^{\circ} \mathrm{C}\right)$; (b) day/night soil temperatures at $25 / 35$ and $35 / 25^{\circ} \mathrm{C}$ are compared with the low temperature control $\left(20 / 20^{\circ} \mathrm{C}\right)$ and constant heat stress $\left(35 / 35^{\circ} \mathrm{C}\right)$; (c) day/night soil temperatures at $30 / 35$ and $35 / 30^{\circ} \mathrm{C}$ are compared with the low temperature control $\left(20 / 20^{\circ} \mathrm{C}\right)$ and constant heat stress $\left(35 / 35^{\circ} \mathrm{C}\right)$. Vertical bars indicate $\operatorname{LSDS}(P=0.05)$ for treatment comparisons on a given day.
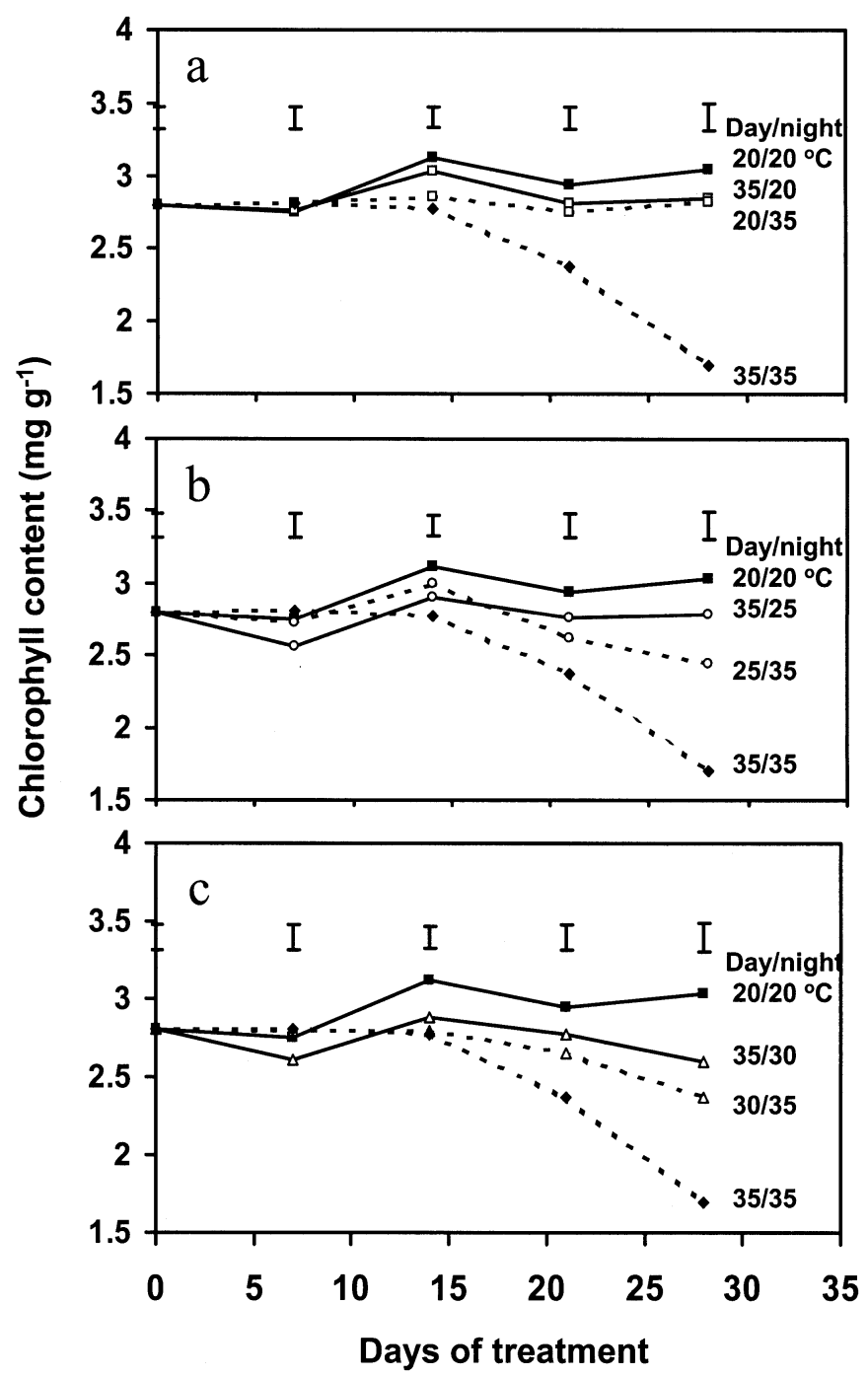

Fig. 4. Leaf chlorophyll content as influenced by lower day or night soil temperatures: (a) day/night soil temperatures at $20 / 35$ and $35 / 20^{\circ} \mathrm{C}$ are compared with the low temperature control $\left(20 / 20^{\circ} \mathrm{C}\right)$ and constant heat stress $\left(35 / 35^{\circ} \mathrm{C}\right) ;(\mathbf{b})$ day/night soil temperatures at $25 / 35$ and $35 / 25^{\circ} \mathrm{C}$ are compared with the low temperature control $\left(20 / 20^{\circ} \mathrm{C}\right)$ and constant heat stress $\left(35 / 35^{\circ} \mathrm{C}\right)$; (c) day/night soil temperatures at $30 / 35$ and $35 / 30$ ${ }^{\circ} \mathrm{C}$ are compared with the low temperature control $\left(20 / 20^{\circ} \mathrm{C}\right)$ and constant heat stress $\left(35 / 35^{\circ} \mathrm{C}\right)$. Vertical bars indicate LSDs $(P=0.05)$ for treatment comparisons on a given day. ments, Inc., Rochester, N.Y). Fresh weight of all roots in each tube was determined weekly after roots were washed free of sand and blotted dry using paper towels. Relative root number was counted weekly using intact roots in two $2 \times 3 \mathrm{~cm}$ areas marked on the opposite sides of each clear plastic bag at 2-cm depth from the soil surface.

\section{Results}

The analysis of variance results indicated that there were significant effects of temperature and time of measurement on all parameters evaluated (Table 1). The interaction between temperature and time of measurement was significant for turf quality, leaf chlorophyll content, leaf growth rate, and root fresh weight, but not for root number.

Turf Quality. Turf quality under constant heat stress $\left(35 / 35^{\circ} \mathrm{C}\right)$ started to decrease below the control level $\left(20 / 20^{\circ} \mathrm{C}\right)$ at $11 \mathrm{~d}$ of treatment (Fig. 3a-c). Reducing soil temperature to 20, 25 , and $30^{\circ} \mathrm{C}$ during the night increased turf quality significantly above the quality level plants maintained at $35 / 35{ }^{\circ} \mathrm{C}$ beginning at $11 \mathrm{~d}$ of treatment. Reducing soil temperature during the day was effective in increasing turf quality only at $20^{\circ} \mathrm{C}$ (Fig. 3a) and $25^{\circ} \mathrm{C}$ (Fig. $3 \mathrm{~b})$ following $11 \mathrm{~d}$ of treatment, but not at 30 ${ }^{\circ} \mathrm{C}$ (Fig. 3c). The reduction in soil temperature at night to $20^{\circ} \mathrm{C}$ when day temperature was $35^{\circ} \mathrm{C}$ resulted in turf quality equivalent to the control during most of the experimental period (Fig. 3a). Lowering soil temperature to $20^{\circ} \mathrm{C}$ at night maintained turf quality at the control level only within the first $14 \mathrm{~d}$ of treatment (Fig. 3a). Plants exposed to lower night temperatures had a higher turf quality than those at lower day temperatures at 20,25 , or $30^{\circ} \mathrm{C}$ after 21 , 11 , and $11 \mathrm{~d}$ of treatment, respectively.

Leaf chlorophyll content. Constant heat stress $\left(35 / 35{ }^{\circ} \mathrm{C}\right)$ reduced chlorophyll content to below levels observed in control plants beginning at $14 \mathrm{~d}$ of treatment (Fig. $4 \mathrm{a}-\mathrm{c}$ ). Reducing soil temperature to 20 (Fig. 4a), 25 (Fig. 4b), or $30{ }^{\circ} \mathrm{C}$ (Fig. 4c) during the night increased leaf chlorophyll content to above the level of plants maintained at $35 / 35^{\circ} \mathrm{C}$ at 14,14 , and $21 \mathrm{~d}$ of treatment, respectively. Reducing soil temperature to 20,25 , or 30 ${ }^{\circ} \mathrm{C}$ during the day also caused an increase in chlorophyll content, which occurred after 21 d for all three treatments. Leaf chlorophyll content was equivalent to the control plants during the entire experimental period when soil temperature was maintained at $20^{\circ} \mathrm{C}$ during the night. The content did not change within the first $14 \mathrm{~d}$ of treatment when soil temperature was reduced during the day (Fig. 4a). Plants grown under lower night soil temperatures contained more chlorophyll than those plants under lower day temperatures after $21 \mathrm{~d}$ at 25 


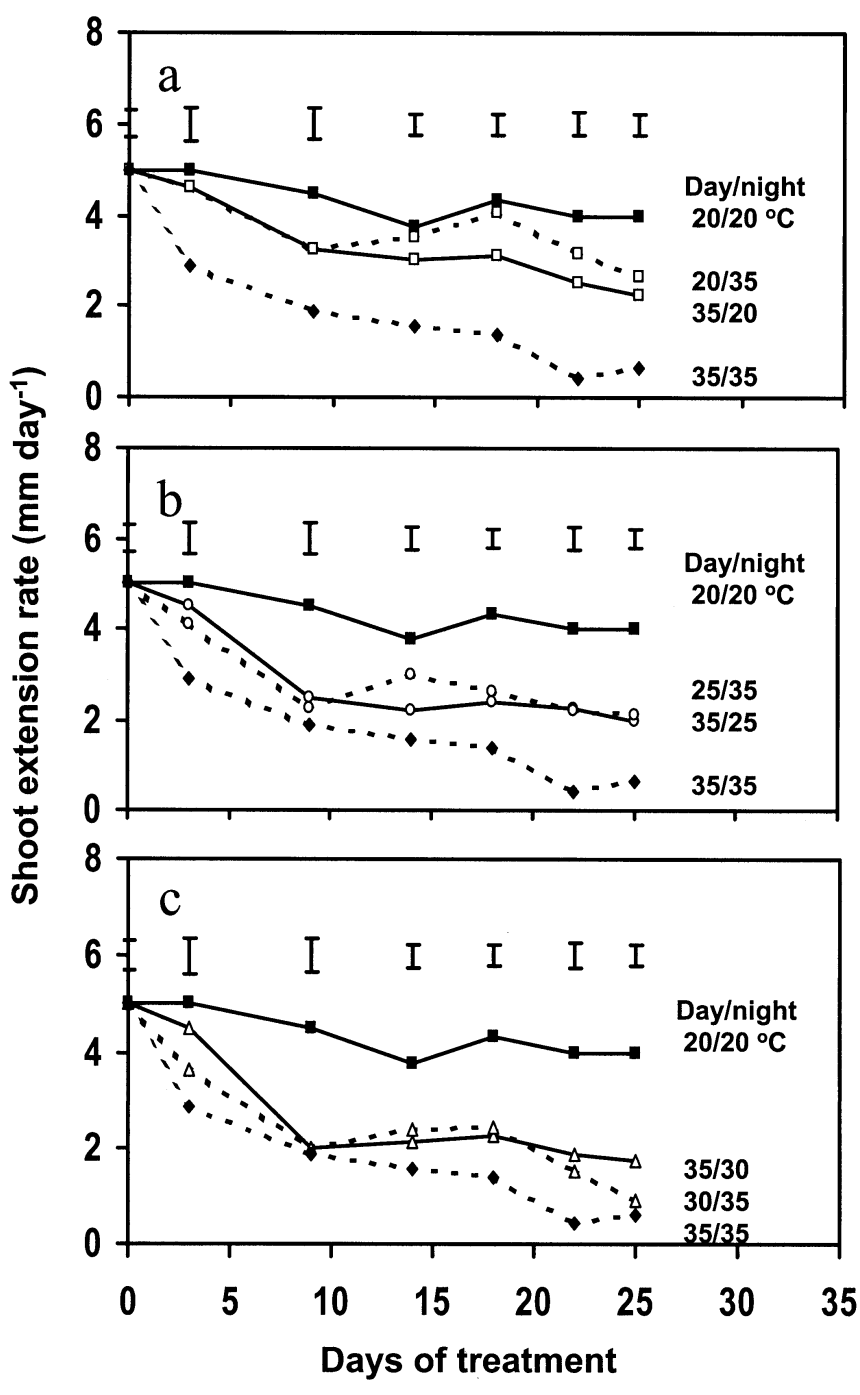

Fig. 5. Shoot extension rate as influenced by lower day or night soil temperatures: (a) day/night soil temperatures at $20 / 35$ and $35 / 20{ }^{\circ} \mathrm{C}$ are compared with the low temperature control $\left(20 / 20{ }^{\circ} \mathrm{C}\right)$ and constant heat stress $\left(35 / 35^{\circ} \mathrm{C}\right)$; (b) day/night soil temperatures at $25 / 35$ and $35 / 25^{\circ} \mathrm{C}$ are compared with the low temperature control $\left(20 / 20^{\circ} \mathrm{C}\right)$ and constant heat stress $\left(35 / 35^{\circ} \mathrm{C}\right) ;(\mathbf{c})$ day/night soil temperatures at $30 / 35$ and $35 / 30$ ${ }^{\circ} \mathrm{C}$ are compared with the low temperature control $\left(20 / 20^{\circ} \mathrm{C}\right)$ and constant heat stress $\left(35 / 35^{\circ} \mathrm{C}\right)$. Vertical bars indicate LSDs $(P=0.05)$ for treatment comparisons on a given day.

or $30^{\circ} \mathrm{C}$ (Fig. $4 \mathrm{~b}-\mathrm{c}$ ).

Vertical shoot extension rate. A significant reduction in shoot extension rate occurred under constant heat stress $\left(35 / 35^{\circ} \mathrm{C}\right)$ beginning at $3 \mathrm{~d}$ of treatment, when compared to the control plants (Fig. 5a-c). Reducing soil temperature to 20 (Fig. 5a), 25 (Fig. 5b), or $30{ }^{\circ} \mathrm{C}$ (Fig. $5 c$ ) during both day and night was effective in improving shoot growth rate, compared to $35 / 35{ }^{\circ} \mathrm{C}$, beginning at $3 \mathrm{~d}$ of treatment and thereafter. Exceptions to the improvement occurred at $8 \mathrm{~d}$ of $35 / 25^{\circ} \mathrm{C}$ and 8 and $25 \mathrm{~d}$ of $35 / 30^{\circ} \mathrm{C}$. Shoot extension rate was higher when soil temperature was reduced to $20^{\circ} \mathrm{C}$ during the day than during the night at 14 , 18 , and $22 \mathrm{~d}$ of treatments (Fig. 5a). No differences in shoot extension rate were found among plants in the day and night treatments at 25 or $30^{\circ} \mathrm{C}$ (Fig. 5 b-c).

Root Growth. Asignificant reduction in root number occurred under constant heat stress
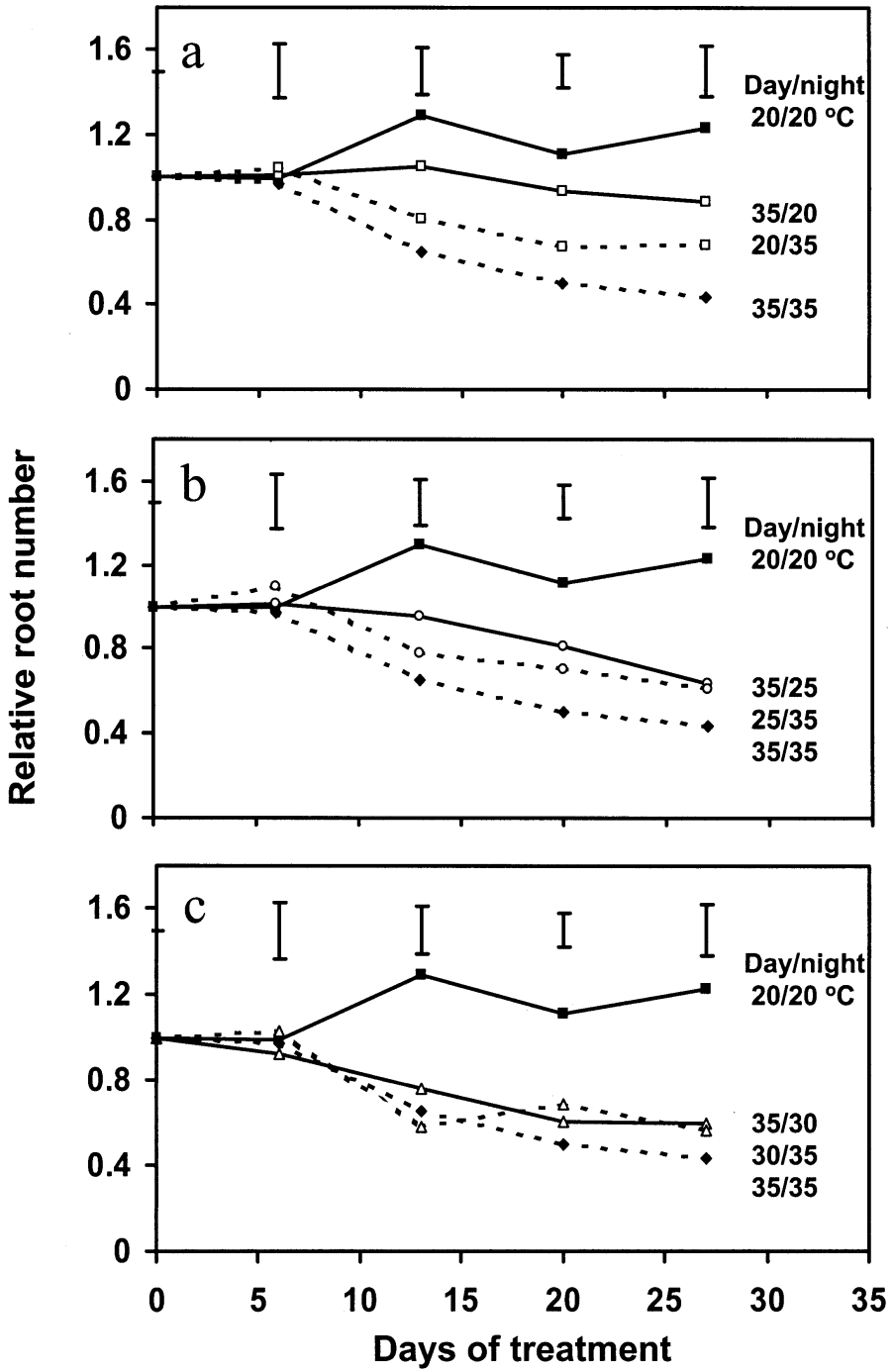

Fig. 6. Relative root number as influenced by lower day or night soil temperatures: (a) day/night soil temperatures at $20 / 35$ and $35 / 20^{\circ} \mathrm{C}$ are compared with the low temperature control $\left(20 / 20{ }^{\circ} \mathrm{C}\right)$ and constant heat stress $\left(35 / 35^{\circ} \mathrm{C}\right)$; (b) day/night soil temperatures at $25 / 35$ and $35 / 25^{\circ} \mathrm{C}$ are compared with the low temperature control $\left(20 / 20^{\circ} \mathrm{C}\right)$ and constant heat stress $\left(35 / 35^{\circ} \mathrm{C}\right) ;(\mathbf{c})$ day/night soil temperatures at $30 / 35$ and $35 / 30{ }^{\circ} \mathrm{C}$ are compared with the low temperature control $\left(20 / 20^{\circ} \mathrm{C}\right)$ and constant heat stress $\left(35 / 35^{\circ} \mathrm{C}\right)$. Vertical bars indicate LSDS $(P=0.05)$ for treatment comparisons on a given day. $\left(35 / 35^{\circ} \mathrm{C}\right)$ beginning at $13 \mathrm{~d}$, when compared to the control plants $\left(20 / 20^{\circ} \mathrm{C}\right.$ ) (Fig. $6 \mathrm{a}-\mathrm{c}$ ). Root number increased to above the level observed at $35 / 35^{\circ} \mathrm{C}$ at 13,20 , and $27 \mathrm{~d}$ after soil temperature was reduced to both 20 (Fig. 6a) and $25^{\circ} \mathrm{C}$ (Fig. 6b) during the night. Root number was not affected at 20 and $27 \mathrm{~d}$ when soil temperature was reduced to $20{ }^{\circ} \mathrm{C}$ (Fig. 6a) during the day. Soil temperature of $30{ }^{\circ} \mathrm{C}$ (Fig. 6c) during the night and 25 (Fig. 6b) and $30{ }^{\circ} \mathrm{C}$ (Fig. 6c) during the day had no effect on root number. Reducing soil temperature to $20^{\circ} \mathrm{C}$ during the night resulted in higher root number than the same soil temperature during the day at 13,20 , and $27 \mathrm{~d}$ of treatment. No significant differences in root number were found between day and night temperature reduction at 25 and $30^{\circ} \mathrm{C}$ (Fig. $6 \mathrm{~b}-\mathrm{c}$ ).

The response of root fresh weight (Fig. 7) to changes in day and night temperatures followed the same pattern as that for root number (Fig. 6).
Plants exposed to lower night temperatures had a $45 \%$ greater root weight than those exposed to lower day temperatures at 20 and $25^{\circ} \mathrm{C}$ at 14 and $28 \mathrm{~d}$ of treatment. Root fresh weight was not different between day and night soil temperature reductions at $30^{\circ} \mathrm{C}$.

\section{Discussion}

Prolonged exposure of roots to lower soil temperatures at 20 and $25^{\circ} \mathrm{C}$ during the day or night suppressed the decline in turf quality, chlorophyll content, shoot extension rate, and root growth compared to the exposure to constant heat stress $\left(35 / 35^{\circ} \mathrm{C}\right.$, day/night even though air temperature was supraoptimal. These results indicate that either day or night soil temperature reduction could lessen heat injury despite high air temperatures. Lowering soil temperature continuously for $24 \mathrm{~h}$ may not be necessary, although it would be effective in 


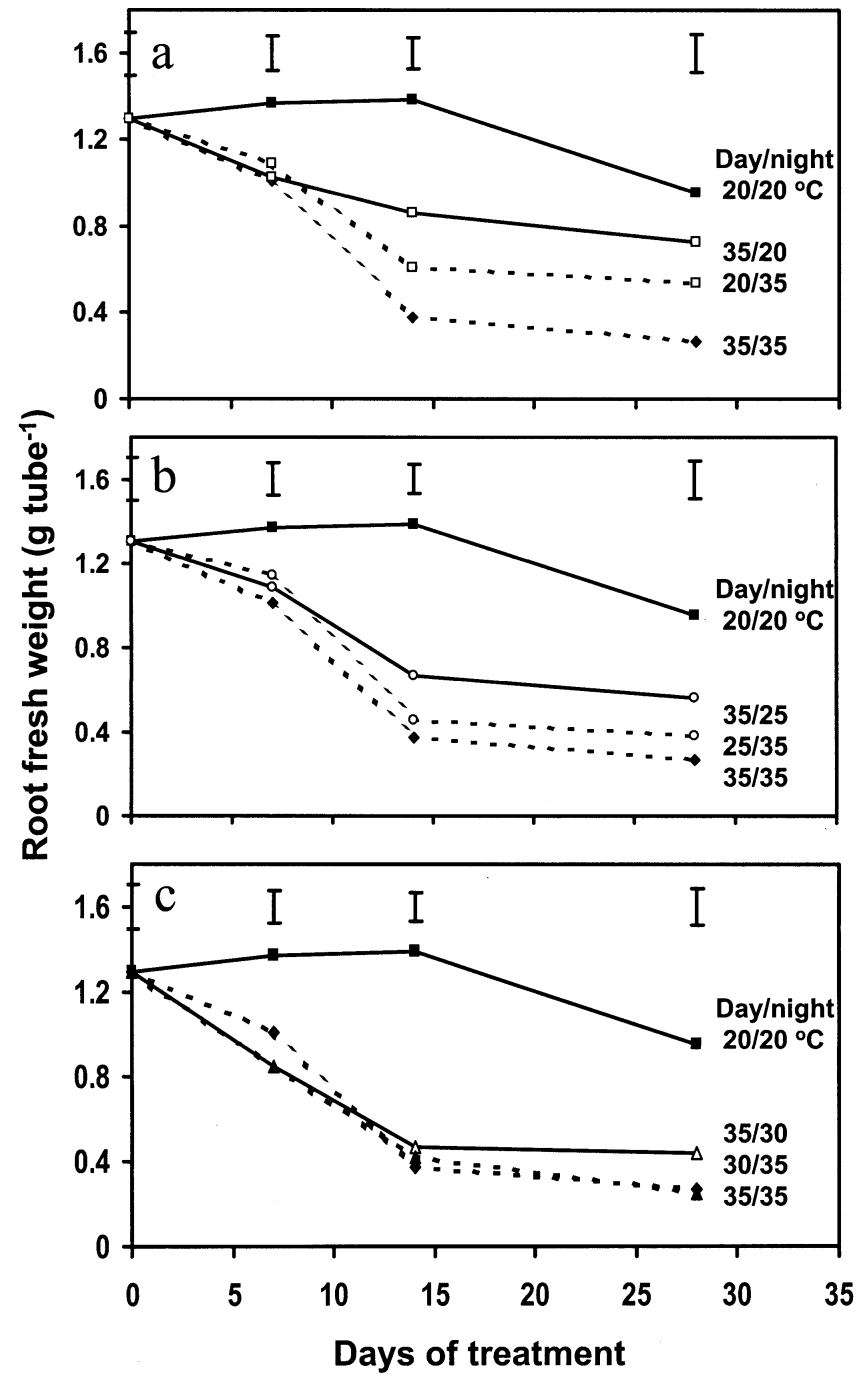

Fig. 7. Root fresh weight as influenced by lower day or night soil temperatures: (a) day/night soil temperatures at $20 / 35$ and $35 / 20{ }^{\circ} \mathrm{C}$ are compared with the low temperature control $\left(20 / 20{ }^{\circ} \mathrm{C}\right)$ and constant heat stress $\left(35 / 35^{\circ} \mathrm{C}\right)$; (b) day/night soil temperatures at $25 / 35$ and $35 / 25^{\circ} \mathrm{C}$ are compared with the low temperature control $\left(20 / 20^{\circ} \mathrm{C}\right)$ and constant heat stress $\left(35 / 35^{\circ} \mathrm{C}\right) ;(\mathbf{c})$ day/night soil temperatures at $30 / 35$ and $35 / 30^{\circ} \mathrm{C}$ are compared with the low temperature control $\left(20 / 20^{\circ} \mathrm{C}\right)$ and constant heat stress $\left(35 / 35^{\circ} \mathrm{C}\right)$. Vertical bars indicate LSDS $(P=0.05)$ for treatment comparisons on a given day.

promoting shoot and root growth under heat stress during summer months (Xu and Huang, 2000a, 2000b, 2001b).

The effectiveness of heat injury alleviation increased as soil temperature was reduced from 30 to $20^{\circ} \mathrm{C}$. Reducing soil temperature during the night to $20^{\circ} \mathrm{C}$ would likely result in quality better than that from constant heat stress. However, lowering soil temperature to $30{ }^{\circ} \mathrm{C}$ during the day had almost no effect on turf quality and root growth. Xu and Huang (2001b) also found that more dramatic improvements of turf quality and shoot and root growth were achieved at $35 / 24^{\circ} \mathrm{C}$ (air/soil) than at $35 / 29$ or $35 / 32^{\circ} \mathrm{C}$ (air/soil). Therefore, soil temperature should be reduced as low as possible on golf greens to achieve better plant growth and turf quality in the summer. Soil temperature reduction by 2 to $3{ }^{\circ} \mathrm{C}$ could be achieved by syringing, installing a soil cooling system, and using fans on golf greens (Carrow, 1996; Dodd et al., 1999; Trusty and Trusty, 1998). Techniques that reduce soil temperature under golf green conditions need to be explored.

Reducing soil temperature to 20,25 , or $30{ }^{\circ} \mathrm{C}$ during the night generally was more effective in improving turf quality than during the day under high air temperature conditions. Night temperature reduction to $20^{\circ} \mathrm{Chad}$ more pronounced effects than day temperature reduction to the same level for enhancing root growth. Cummings et al. (1999) reported that fresh root biomass decreased linearly with increasing night soil temperature from 22 to 34 ${ }^{\circ} \mathrm{C}$ for creeping bentgrass and annual bluegrass (Poa annua L.). However, they did not compare the effects between day and night temperatures on root growth. Research with other species indicated that night air temperature was more important than day temperature for plant growth in tomato (Lycopersicon esculentum) (De Koning, 1988), soybean (Glycine max L.) (Thomas et al., 1981), and several subtropical grasses (Ivory and Whiteman, 1978). Tomato plants grew substantially faster at high day and low night air temperatures than at low day and high night temperatures (De Koning, 1988). Lowering night air temperature was more effective than lowering day air temperature for leaf growth, but not for stem growth in soybean (Thomas et al., 1981).

Plants' temperature requirements for producing maximum potential growth are generally lower for night temperatures than for day (Ivory and Whiteman, 1978; Ku et al., 1977; Teeri and Stowe, 1976). Diurnal temperature fluctuation favors higher photosynthetic rates during the day and lower respiration rates at night (Thomas et al., 1981). Greater effectiveness of night vs. day temperature reduction in improving shoot and root growth under heat stress could be associated with differences in carbohydrate metabolism between day and night (Xu et al., 2003). The mechanisms of the differential effects of lowering day and night soil temperatures on creeping bentgrass deserve investigation.

In summary, the results of this study indicate that lower soil temperature during the day or night alone generally was effective in improving both shoot and root growth of creeping bentgrass when air temperature is supraoptimal. Soil temperature reduction during the night was more effective for producing higher turf quality than during the day. If soil temperature is lowered during the day rather than night, a greater level of soil temperature reduction may be needed to achieve enhancement in turf and root growth. Cultural management practices that reduce soil temperatures to a cooler level during the night may be paramount.

\section{Literature Cited}

Beard, J.B. 1973. Turfgrass: Science and culture. Prentice-Hall, Englewood Cliffs, N.J.

Beard, J.B. and W.H. Daniel. 1965. Effect of temperature and cutting on the growth of creeping bentgrass (Agrostis palustris Huds.) roots. Agron. J. 57:249-250.

Carrow, R.B. 1996. Summer decline of bentgrass greens. Golf Course Mgt. 64:51-56.

Cummings, H.C., T.W. Rufty, and F.H. Yelverton. 1999. Root growth responses of 'Penncross' creeping bentgrass and annual bluegrass to various diurnal root-zone temperatures. 1999 Annu. Mtg. Abstr. 91:139.

De Koning, A.N.M. 1988. The effect of different day/night temperature regimes on growth, development and yield of greenhouse tomatoes. J. Hort. Sci. 63:465-471.

Dodd, R., B. Martin, and J. Camberato. 1999. Subsurface cooling and aeration. Golf Course Mgt. 67:71-74.

Hiscox, J.D. and G.F. Israeltem. 1979. A method for extraction of chlorophyll from leaf tissue without maceration using dimethyl sulfoxide. Can. J. Bot. 57:1332-1334.

Hoagland, D.R. and D.I. Arnon. 1950. The waterculture method for growing plants without soil. Circ. 347. California Agr. Expt. Stn.

Huang, B., X. Liu, and J.D. Fry. 1998. Shoot physiological responses of two bentgrass cultivars to high temperature and poor soil aeration. Crop Sci. 38:1219-1224.

Ivory, D.A. and P.C. Whiteman. 1978. Effect of temperature on growth of five subtropical grasses. I. Effect of day and night temperature on growth and morphological development. Aust. J. Plant Physiol. 5:131-148. 
Ku, S.B., G.E. Edwards, and D. Smith. 1977. Photosynthesis and nonstructural carbohydrate concentration in leaf blades of Panicum virgatum as affected by night temperature. Can. J. Bot. 56:63-68.

Lucas, L.T. 1995. Bentgrass summer decline. North Carolina Turfgrass Summary. 32-33.

Poorter, H., A. van der Werf, O.K. Atkin, and H. Lambers. 1991. Respiratory energy requirements of roots vary with the potential growth rate of a plant species. Physiol. Plant. 83:469-475.

SAS Institute. 1996. SAS user's guide: Statistics, $6^{\text {th }}$ ed. SAS Inst., Cary, N.C.

Taylor, G.R. 1995. The effects of mechanically induced air movement on the temperature, leaf water potential and soil moisture percentage of creeping bentgrass (Agrostis stolonifera L.). Golf Green. MS Thesis.

Teeri, J.A. and L.G. Stowe. 1976. Climate pattern and the distribution of C4 grasses in North America. Oecologia 23:1-12.

Thomas, J.F., C.D. Raper Jr., and W.W. Weeks. 1981 Day and night temperature effects on nitrogen and soluble carbohydrate allocation during early reproductive growth and soybeans. Agron. J. 73: 577-582.

Trusty, S. and S. Trusty. 1998. Hot town cool bentgrass. Golf Course Mgt. 66:186-191.

Xu, Q. and B. Huang. 2000a. Growth and physiological responses of creeping bentgrass to changes in air and soil temperatures. Crop Sci. 40:1363-1368.
Xu, Q. and B. Huang. 2000b. Effects of differential air and soil temperature on carbohydrate metabolism in creeping bentgrass. Crop Sci. 40 1363-1368.

Xu, Q. and B. Huang. 2001a. Morphological and physiological characteristics associated with heat tolerance in creeping bentgrass. Crop Sci. 41:127-133.

Xu, Q. and B. Huang. 2001b. Lowering soil temperatures improves creeping bentgrass growth under heat stress. Crop Sci. 41:1878-1883.

Xu, Q., B. Huang, and Z. Wang. 2003. Effects of extended daylength on shoot growth and carbohydrate metabolism for creeping bentgrass exposed to heat stress. J. Amer. Soc. Hort. Sci. (In press.) 